\title{
The Rational Agent or the Relational Agent: Moving from Freedom to Justice in Migration Systems Ethics
}

Tisha Rajendra

Loyola University Chicago, trajendra@luc.edu

Follow this and additional works at: https://ecommons.luc.edu/theology_facpubs

Part of the Religious Thought, Theology and Philosophy of Religion Commons

Author Manuscript

This is a pre-publication author manuscript of the final, published article.

\section{Recommended Citation}

Rajendra, Tisha. The Rational Agent or the Relational Agent: Moving from Freedom to Justice in Migration Systems Ethics. Ethical Theory and Moral Practice, 18, 2: 355-369, 2014. Retrieved from Loyola eCommons, Theology: Faculty Publications and Other Works, http://dx.doi.org/10.1007/

s10677-014-9522-z

This Article is brought to you for free and open access by the Faculty Publications and Other Works by Department at Loyola eCommons. It has been accepted for inclusion in Theology: Faculty Publications and Other Works by an authorized administrator of Loyola eCommons. For more information, please contact ecommons@luc.edu. cc) (i) $(9)$

This work is licensed under a Creative Commons Attribution-Noncommercial-No Derivative Works 3.0 License. (c) Springer Netherlands, 2014. 
The Rational Agent or the Relational Agent:

Moving from Freedom to Justice in Migration Systems Ethics

\section{Acknowledgments}

This article has greatly benefitted from the revisions and suggestions of Hille Haker, Sandra Sullivan Dunbar, the attendees of the 2012 Conference on Poverty, Coercion and Human Rights at Loyola University Chicago and the anonymous peer reviewers for this journal.

\section{Introduction}

Behind every immigration policy proposal lies an implicit account of who the migrant is and why she decided to leave home. For example, a proposal to build a wall on the southern United States border assumes that a migrant is primarily a rational agent who chooses to migrate in search of better life opportunities. Guestworker program proposals likewise assume that migrants are desperate for work opportunites. In these proposals, the political community is called upon to assist migrants in securing better lives for themselves, even as the community retains the right and the duty to control its membership. Though they are strikingly different, both proposals assume that poverty and lack of opportunities drive migration.

Such policy proposals, I will argue, are implicitly based in neoclassical migration theory, a theory that assumes that migrants are exclusively rational agents who migrate in search of better life opportunities. Despite the intuitive appeal of this theory, most migration theorists reject it in favor of more complex theories: world systems theory, historical structural theory, the new economics of migration, and migration systems 
theory. ${ }^{1}$ Because migration theory is an interdisciplinary field, each of these theories draws on different methodologies from different field of study. However, in this paper, I argue that different migration theories implicitly draw upon different accounts of the human person. ${ }^{2}$

In the course of this paper, I will show that neoclassical migration theory is based on an account of the human person as an autonomous, rational agent, motivated exclusively by the maximization of his own utility and operating in a cultural, historical, social and political vacuum. The ethics of migration that either implicitly or explicitly adopt this theory also adopt this view of the person, leading to normative claims that focus exclusively on increasing the freedom of either migrants or citizens. I reject this account of the person, drawing instead on feminist accounts of the person that emphasize relationality in addition to autonomy. Adopting this view of the person entails rejecting neoclassical migration theory in favor of another migration theory, migration systems theory, which presumes a fuller account of the person. I conclude the paper with some directions for an ethic of migration that presumes migration systems theory rather than neoclassical migration theory. This ethics must be based on the idea of justice-in-relation rather than the maximization of freedom.

This paper has four sections. Part I is a presentation and evaluation of neoclassical migration theory as presented by migration theorist George Borjas. Part II examines the work of three political philosophers who implicitly ground their work in the anthropological assumptions of neoclassical migration theory: Joseph Carens, Michael

\footnotetext{
${ }^{1}$ For a thorough review of the literature of each theory, see (Massey et al. 2005) and (Castles and Miller 2009).

${ }^{2}$ An additional explanation for the proliferation of different migration theories is that no one migration theory seems to be able to account for all of the data (Portes 1997: 810; Massey et al. 2005).
} 
Walzer, and David Miller. Part III is a presentation of migration systems theory and exploration of the anthropological assumptions behind it. Part IV presents some directions for an ethics of migration that responds to migration systems theory and its account of the human person.

I wish to delimit the scope of my argument in several ways.

First, I primarily focus on "voluntary" economic migration. Although many theorists have questioned the legitimacy of the distinction between voluntary and involuntary migration, for the purposes of this paper, I set aside issues of forced migration and human trafficking (Skeldon 1997; Faist 2000).

Second, migration theories address both the determinants of migration (why and how people migrate) and theories of immigration incorporation (i.e. how immigrants adapt to and settle in the receiving country). Since the ethicists of migration I critique are drawing on implicit claims about what draws migrants to the developed world, I focus on theories that address the determinants of migration.

Third, migration theorists study all human movement, including regional migration within one nation-state and transnational migration within Asia, Africa, and Latin America. The theorists I discuss in this paper are primarily concerned with transnational migration from the developing world to Western democracies. I follow their lead by focusing on similar transnational migration patterns.

Fourth, while any discussion of the ethics of migration necessarily invokes immigration policy, this argument is not primarily a policy proposal; it is an attempt to reformulate how we think about migrants, citizens, and the relationships between them. 


\section{The Rational Agent of Neoclassical Migration Theory}

In order to examine the anthropological assumptions grounding neoclassical migration theory, I turn to the work of U.S. economist George Borjas. Although Borjas is considered a "leading expert" on immigration policy, he is a controversial figure; his methods, data and conclusions are the object of much debate, even among labor migration economists. ${ }^{3}$ In his two books on immigration policy, Friends or Strangers (1990) and Heaven's Door (1999), Borjas argues that the United States must instantiate policies that attract more skilled and educated migrants. Borjas insists that he is merely presenting data, leaving the ethics of migration to others, (Borjas 1990: 220; Borjas 1999: 186-187) but neither the data Borjas presents nor his policy recommendations are ethically neutral. Borjas makes claims about the human person and about migration processes that have direct ethical implications. His fundamental assumption, shared by many who shape immigration policy, does not change between these two books, but it is more explicitly stated in Friends or Strangers, namely that migrants and citizens are free, unencumbered rational agents.

Borjas asserts that the problem with U.S. immigration is not the number of immigrants, either undocumented or legally admitted; rather, Borjas argues that the U.S. has an immigration problem because of the type of immigrants who come to the U.S.: unskilled migrants with low levels of education (Borjas 1990: 22; Borjas 1999). Borjas argues that these low-skilled immigrants drive down average per capita income because of their low wages, burden the welfare system, and lower the wages of the immigrants already in the U.S. (Borjas 1990: 20-21; Borjas 1999: Ch. 5-6) Borjas uses neoclassical

\footnotetext{
${ }^{3}$ For an excellent layperson's summary of the debates between economists on immigration and its impact on domestic labor markets, see (Lowenstein 2006).
} 
economic models to describe how the U.S. might attract higher skilled migrants. Both his policy prescriptions and criticisms are rooted in an account of the human person as an exclusively rational agent.

For Borjas, a migrant in search of a receiving country is like a worker in search of a job. "Like persons looking for work, potential migrants enter the market, receive offers from competing host countries and their home country, compare the offers and make a migration decision” (Borjas 1990: 20-21). Having weighed each of these competing offers, the migrant chooses the opportunity that will maximize her happiness. Wage differentials between countries lead to increased immigration from low wage countries to the high wage countries. Poverty and unemployment drive workers to migrate to receiving countries in search of better opportunities.

According to Borjas, wage differentials between any two countries would lead to migration. Each individual migrant decides anew where s/he would be best off and makes the decision to migrate based on the evaluation of the opportunities that various countries afford. The person in neoclassical migration theory, as Borjas employs it, makes decisions about his utility in a social, political, and cultural vacuum. ${ }^{4}$ Neoclassical migration theorists could in theory work relational factors into the neoclassical paradigm, for example, a migrant might decide to go where there is an established community of other migrants because this community might increase his utility. However, most neoclassical migration theorists focus almost exclusively on wage differentials and

\footnotetext{
${ }^{4}$ While Borjas does acknowledge that individuals are members of families that often play a role in making decisions about migration, Borjas uses the same assumptions when he makes families the subject of decision-making rather than individuals: "In fact, it is families who enter the immigration market, compare the various offers, and choose the option that maximizes the household's economic well-being” (Borjas 1990: 188). In this case, it is the family who are the rational actors instead of individuals. Borjas is drawing on the research of migration systems theorists who would not support the neoclassical model by mapping the data onto his own anthropological assumptions.
} 
employment opportunities. Borjas cites the example of the United States and Sweden to show how wage differentials would work. Because highly skilled work is better remunerated in Sweden than the United States, Borjas predicts that highly skilled Swedes would naturally want to migrate to the United States. ${ }^{5}$ The fact that there has been no large-scale pattern of Swedish migration to the United States in the late $20^{\text {th }}$ century does not lead Borjas to question his assumptions. ${ }^{6}$

Although migration theorists have long criticized neoclassical migration theory for its inability to fully account migration data, in particular why certain communities of migrants go to one country and not another, I will focus not on the predictive shortcomings of this theory, ${ }^{7}$ but on the ethical shortcomings of Borjas's rational man anthropology. These shortcomings are most obvious when we examine the ethical implications of Borjas's neoclassical assumptions for undocumented workers.

Borjas' claims that undocumented migrants enter territories illegally as a result of the same calculus that drives legal migration: the benefits outweigh the costs. This leads Borjas to conclude that reports of the exploitation and abuse of undocumented workers must be overblown. "After all, these persons are in the United States voluntarily. They willingly entered the black market for immigrants, and they obviously benefit from being in the United States, for otherwise they would simply return to their country of origin where they could avoid the exploitation and stigma attached to illegal status,” (Borjas 1990: 72).

\footnotetext{
${ }^{5}$ Borjas attributes this to the fact that the cost of migrating from Sweden to the United States would exceed the small benefit of increased wages. (Borjas 1999: 49)

${ }^{6}$ There was some migration from Sweden to the U.S. at the turn of the 20th century. However, the circumstances that began that particular migration flow ended with the Swedish reforms of 1907. Soon after, World War I interrupted that particular migration flow.

${ }^{7}$ See, for example, Skeldon 1997; Sassen 1999: Preface; Massey et al. 2005: 8-11.
} 
Borjas appears not to be aware of the well-documented exploitation of undocumented workers, from wage exploitation to extended detainment to outright slavery. Perhaps, Borjas' anthropology leaves him unable to analyze the abuse of undocumented migrants any other way. The rational actor account of the human person makes the granting or denial of freedom the primary and perhaps only measure of well-being: if the undocumented migrants have the freedom to stay or go, then they cannot be truly oppressed or exploited.

Borjas's neoclassical model shows that anthropological assumptions about migration affect not only the theoretical models we use, but also the ethical analyses of migration. While Borjas is not an ethicist, I now turn to the work of Joseph Carens, Michael Walzer, and David Miller in order to show how an ethical adaptation of neoclassical migration theory leads to similarly inadequate normative claims.

\section{The Rational Agent of Migration Ethics}

\section{Joseph Carens}

Canadian-American political philosopher Joseph Carens has long defended the idea of open borders, arguing that liberal societies have no basis upon which to forcefully exclude needy and decent non-citizens (Carens 1987). The heart of Carens' argument is that if we assume that people are of equal moral worth, then people ought to be granted the same freedom of movement across the borders of nation-states that they are granted within states. Conversely, the denial of freedom of movement to non-citizens who wish to enter exacerbates economic inequalities, and as such, is a violation of human rights. (Carens 1987; Carens 2013: Ch. 11). Carens' argument certainly presents an important 
challenge to those who take for granted the idea that the sovereignty of the state entails the right to exclude would-be migrants. In this paper, I do not wish to directly engage Carens' open borders argument, but rather to examine the theoretical assumptions behind it. While Carens does not explicitly draw on any migration theory, he presumes a neoclassical model of migration that, like Borjas', overemphasizes freedom.

Though the substance of Carens' argument is relatively simple, he is careful to circumscribe this argument so that it is not misunderstood. Carens is not making a public policy proposal. He knows very well that his argument is so far outside the mainstream policy discourse as to be irrelevant in the public and policy sphere. (Carens 1996; Carens 1997; Carens 2000: 643) Rather, his purpose in making this argument is to question the assumption that the system of nation-states, which secures privileges for the few and poverty for the many, is natural and good.

Carens is not arguing for a world-state, nor is he arguing for a world without states. In his vision, states would still control admission to their territory, granting priority admission to the most needy and excluding those who present a threat to the political community. (Carens 2003: 105-106; Carens 2013: 231) Liberal states should operate under the presumption that everyone who wishes to enter would be admitted as soon as the state could process their admission. Carens moderates his cosmopolitanism by saying that the political community does have stronger obligations to its own members; however, the state does not have the right to exclude someone from becoming a member (Carens 2000). If a non-member wants to sign the social contract and thus become a member, she should be able do so. Carens is not arguing against sovereignty and communal self-determination, but merely arguing that neither entail the right to exclude. 
Carens never explicitly states that he relies on neoclassical migration theory, but his open borders argument adopts the key assumption of neoclassical migration theory: people migrate in search of better opportunities. Thus, for Carens, restrictions on the freedom of movement are morally problematic because they interfere with the freedom of migrants to pursue better life opportunities for themselves. An open borders policy would grant these opportunities to migrants by granting migrants the freedom to chose one's own path regardless of where one lives.

Carens' optimism about the maximization of migrant freedom reveals, however, that ultimately, he envisions justice for migrants as this maximization of freedom. For one thing, Carens conflates this freedom of movement with economic equality. "Freedom of movement would contribute to a reduction of existing political, social, and economic inequalities." (Carens 2013: 228) He acknowledges that open borders alone cannot solve questions of global poverty; open borders must be just one aspect of global distributive justice. (Carens 2013: 233-236) But in fact, studies on "brain drain” suggests that open borders may exacerbate global inequalities as citizens with the education and skills flee. ${ }^{8}$

According to Carens, open borders would still contribute to equality of opportunity even if they cannot reduce global inequality. (Carens 2013: 235-236) Carens' optimism about open borders reveals his reliance on neoclassical migration theory, which suggests that once migrants have relocated, they have maximized their opportunities to the greatest degree possible. In fact, unless access to basic goods is protected for migrants and citizens alike, open borders are unlikely to improve either economic inequality or equality of opportunity.

\footnotetext{
${ }^{8}$ For a brief overview of the phenomenon of "brain drain," see (Carrington 1999)
} 
Carens is not opposed to securing access to basic goods for migrants. He repeatedly emphasizes that the goal of open borders is politically infeasible, and that more proximate goals of reforming immigration policy are critical for securing the human rights of migrants within a closed-border system (Carens 1997). Despite Carens’s circumscription of his argument, I would suggest that Carens’ still risks neglecting concerns about justice for migrants because of his emphasis on the freedom of movement of migrants. In a 2008 article, Carens expresses ambivalence about Canada's temporary migrant worker program (Carens 2008). Carens' analysis of this program veers between neoclassical migration theory and segmented labor market migration theory, which suggests that migration is the result of the demand for cheap labor in the developed world. In the parts of the article where he is implicitly drawing upon segmented labor market theory, he points to the morally problematic elements of the program. In the parts of the article where he implicitly draws upon neoclassical migration theory, he wonders whether the opportunities that such a program affords migrants workers might render it more tolerable.

In other words, neoclassical migration theory and its focus on rational choice obscures the human rights issues surrounding migration. Would open borders really secure migrant human rights if immigrants were only "free" to take the most dangerous and low-paying jobs? How would open borders secure economic equality if only those with the resources to migrate were really free to pursue opportunities in other countries? With the framework of neoclassical migration theory, Carens' open borders argument is limited in its ability to tackle migration's many ethical dilemmas. 


\section{Michael Walzer and David Miller}

While Joseph Carens assumes neoclassical migration theory in his argument that borders should be open, Michael Walzer and David Miller implicitly rely on neoclassical migration theory in assuming that borders should be closed. Walzer's Spheres of Justice and Miller's National Responsibility and Global Justice were written almost twenty-five

years apart. At heart, however, their arguments that the political community has the right to choose its own members are so similar that I will consider them together. Both Walzer and Miller hinge their argument for closed borders on the assumption that the right to choose members is central to the self-determination of the political community. Although Walzer and Miller have a communal rather than individual account of self-determination, I argue that this focus on self-determination leads to an ethical dead-end where migrants are pitted against citizens.

Michael Walzer's discussion of citizenship and borders is rooted in his account of justice. For Walzer, all social goods must be distributed in accordance with the meanings ascribed to them by a community. Membership is "conceivably the most important social good" that members of the political community distribute to non-members because this allocation of membership determines who can partake in the creation and distribution of all the other goods in the political community (Walzer 1983: 29). The ability of a political community to choose its own members stems from its right of self-determination; the political community has the right to determine its own identity and composition. Walzer even goes so far as to defend Australia's "White Australia” immigration policy, which until the 1950s favored British and other white immigrants over non-whites. No matter how morally distasteful we may find such a policy, Walzer writes that Australia, like 
every political community, has a common life; "their comrades and associates are theirs to recognize or choose," 9 (Walzer 1983: 48).

Though most of Walzer's discussion of membership is concerned with exceptions to the right of the political community to choose its own members, Walzer's discussion of migration in general reveals his assumptions about why people become migrants. "Since human beings are highly mobile, large numbers of men and women regularly attempt to change their residence and their membership, moving from unfavored to favored environments. Affluent and free countries are, like élite universities, besieged by applicants”(Walzer 1983: 32). Thus Walzer adopts the central assumption of neoclassical migration theory: that people become migrants in order to maximize their utility. Walzer's affirmation of the right of the political community to choose its members takes place in the context of his assumptions about migration theory: the political community must maintain its integrity against a possible invasion of needy migrants.

Most of Walzer's discussion of membership is occupied with the exceptions to his strong account of communal self-determination. In some cases, the claims of necessity and justice can compel a political community to admit non-members. Refugees, "whose need is for membership itself," have a right not to be returned to their countries of origin. Guestworkers may not be admitted to a territory without a corresponding offer of full citizenship. But when examining Walzer's discussions of refugees, Athenian metics, and Turkish guestworkers, it is important to remember that these cases are the exceptions to Walzer's stance rather than the rule.

\footnotetext{
9 Walzer does limit Australia's claim to unoccupied land in the face of tremendous need of its neighbors, but Walzer affirms that Australia could have ceded land without granting admission to non-whites.
} 
Many political philosophers who do not share Walzer's method nevertheless draw on his discussion of membership, because they consider the right of the political community to choose its own members foundational to self-determination. ${ }^{10}$ Unlike Walzer, who generally refrains from making pronouncements about the human condition, David Miller writes from a straight-forwardly liberal perspective, basing his argument on two broad premises about the human person: the human person is needy and vulnerable and is a choosing agent (Miller 2007: 5-6). But like Walzer, Miller also concludes that political communities have the right to choose their members, in part because he also frames migration as a question of the freedom of movement of migrants versus the selfdetermination of the political community. He writes that the central ethical question of immigration is "whether basic human rights include the right to cross national borders and live in a territory of one’s own choosing” (Miller 2007: 201). By framing the central question as a question of individual rights, Miller invokes the central assumption of neoclassical migration theory: that migration is the result of individual choices. Although Miller shares Walzer's position that peoples have the right to determine their composition by controlling their borders and setting immigration policy (Miller 2007: 223), he also argues needs of migrants may mean that the political community has the moral obligation to respect the freedom of migrants to find a new home. I will show that Miller's reliance on neoclassical migration theory leaves him framing migration as a contest between the rights of migrants and the rights of citizens without a clear way to determine whose rights should take precedence and why.

Much of Miller's argument about the communal self-determination of the political community is refutations of scholars like Carens, who argue the rights of migrants take

${ }^{10}$ For example, see (Rawls 1999: 39n) 
precedence over the rights of communities to exclude them. Miller thus argues that communal autonomy and self-determination give political communities the right to their own territory and the right to determine the composition of their communities. This gives political communities the right to exclude non-members, whose right to freedom of movement cannot override the self-determination of the political communities they seek to enter. Miller does diverge somewhat from the rational agent-dominant analysis of those like Borjas and Carens by considering the responsibilities of the political community to would-be migrants. This is a major theme of National Responsibility and Global Justice, which weighs the responsibilities of political communities to outsiders. Even though this focus on responsibility rather than freedom and rights is helpful, Miller's assumptions about how and why migration occurs hinders him from accurately assessing what these responsibilities may be.

Miller limits the moral responsibility to admit migrants to cases where the fundamental needs of migrants are under threat. In other words, although Miller does not directly invoke neoclassical migration theory, his assumption that migration is a choice that must only be accommodated in dire circumstances implicitly assumes that the fundamental ethical problem of migration is the problem of how to reconcile the rights of migrants with the rights of the political community.

In presenting the central problem of transnational migrant as the competition of these two irreconcilable rights, Miller ends with a somewhat muddled account of how these two rights must interact with one another. He avoids specifying when and how the rights of the political community must yield to the freedom of desperate migrants. At times he states that the political community has responsibilities to needy migrants; in other places, 
he states that no one can compel the political community to admit these migrants. Ultimately, it seems that despite Miller's concern for needy migrants, he cannot override the right of the state to exclude. Even in the face of tremendous need, the political community cannot be compelled to admit refugees; the duty to shelter them only extends to the principle of nonrefoulement: a political community cannot return refugees to their homes where they face persecution and death. Ultimately, the decision about whether and how many refugees to admit must be left up to the state (Miller 2007: 226).

Walzer and Miller do not arrive at the same normative conclusion as Carens, but all three frame the ethical issues surrounding migration as a conflict between the rights of migrants and the rights of the political community. Though neither Walzer nor Miller describe who migrates and why, they implicitly assume that migrants are needy and distant others, clamoring to enter the political community. The political community, for its part, must protect its identity by controlling the number and composition of strangers who enter. In the vast majority of cases, the moral claims that desperate strangers have on members are minimal indeed, precisely because they are strangers. In the thought of Carens, Walzer, and Miller, the rights of migrants and citizens are pitted against one another. Either we must protect migrants by protecting the right to migrate, or we must protect the self-determination of a political community by enforcing the right to choose new members. In these ethics of migration, migrants and citizens are both ahistorical, atomized groups with no relationship to one another or accountability to one another, aside from the principle of mutual aid.

This overemphasis on freedom and self-determination obscures what migration is and how it works. Though neoclassical migration theory would predict people in the 
world's poorest countries who have most to gain from membership in an affluent liberal democracy would be the most likely to migrate, the poorest people in the world are not likely to migrate because they often do not have the resources to do so (Skeldon 1997). While many migrants do come from situations of poverty, neoclassical migration theory does not tell the whole story of migration. Likewise, the ethical theories that implicitly rely on neoclassical migration theory do not tell the full story of the human person.

Only when we have a fuller account of migration can we develop ethical theories that better address both the phenomenon of migration and the reality of the human person.

\section{Migration Systems Theory: Autonomy-in-Relationality}

In contrast to neoclassical migration theories, in which the migrant is considered to be a rational agent seeking to maximize her utility, migration systems theory considers the migrant in her social, political, historical and economic context. The basic principle of migration systems theory is that migration flows are the result of interacting macrostructures of geopolitical relationships often rooted in history, and meso-structures of informal social networks that migrants have with one another (Faist 2000). Migration systems, in which two or more countries exchange large numbers of migrants, rarely arise spontaneously; ${ }^{11}$ they are the result of these pre-existing relational structures. In other words, migration systems result from relationship rather than rational choice alone.

The macro-structures of migration include "the political economy of the world market, interstate relationships, and the laws, structures, and practices established by the

\footnotetext{
11 There are instances where small migration flows have been initiated by one person or a small group of people. See Kritz and Zlotnik 2009.
} 
states of sending and receiving countries” (Castles and Miller 2009: 28). In other words, migration flows are a corollary to other types of relationships between countries:

historical, economic, and political. While all of these relationships affect migration flows, migration systems theorists emphasize that many large scale migration flows have their origins in the actions of states: conquests, colonialism, and the deliberate organized recruitment of guest workers (Portes and Böröcz 1989: 608). Indeed, some of the largest migration flows have their roots in conquests and colonialism. Immigrants from the Maghreb and francophone West Africa most often migrate to the former colonial power, France, rather than the economically more prosperous Switzerland. Similarly, large flows of migrants from South Asia go to the United Kingdom. Migration flows rooted in historical relationships are not limited to traditional colonialism. For instance, although the United States had no colonies (with the exception of the Philippines), quasi-colonial relationships with countries like El Salvador and Guatemala have initiated migration systems to the U.S.

Organized recruitment has also generated large migrant flows into developed countries. 2.6 million Turks make up three percent of the German population, due to Germany’s post-war guestworker program. Similar guestworker programs brought Mexicans to the United States, Italians to Switzerland and Moroccans and Algerians to France. While the guestworker programs were intended as temporary solutions to shortterm labor shortages, in every case, guestworker programs led to increased permanent migration as guestworkers remained in the country and eventually reunited their families in their new homes. In the parlance of migration systems theory, the guestworker programs initiated migration systems that continue to this day. 
Migration systems can also be initiated by economic relationships between countries. Foreign investment in factories that make goods for export disrupts traditional work structures, creating a vast pool of unemployed laborers (Sassen 1988: 17-19). In addition, these workers become "westernized" through exposure to Western culture (Sassen 1988: 20).

Once a migration system is in place, it is sustained by migrant networks, the mesostructures developed by the migrants themselves. Social networks such as families, communities, small immigrant-owned businesses help new migrants follow the path of people who have already migrated by enabling them to pool knowledge and resources that ease the transition to their new homes (Faist 2000; Castles and Miller 2009: 29) Migrant networks help potential and new migrants learn how to migrate, find employment opportunities in the host country, and navigate in a new social, political, linguistic and cultural context (Castles and Miller 2009: 29). Immigrants may sponsor family members; once the new migrant arrives social and familial networks help the new migrant acclimate to her new surroundings. In other words, "each act of migration alters the social context within which subsequent migration decisions are made, typically in ways that make additional movement more likely” (Massey et al. 2005: 45-46). Migrant networks can also include criminal infrastructure like human smugglers and traffickers. Migrant networks include marks of the industriousness and creativity of migrants who establish new businesses, community centers, and social networks for their communities.

Migration theorists do not deny that push factors like poverty and unemployment play a role in migration, nor do these theorists ignore the importance of labor markets in developed countries. But these economic factors are never considered apart from the 
larger macro-structures that often generate migration flows. The economic factors at work in migration do not occur in a political, demographic, or social vacuum (Kritz and Zlotnik 1992: 3). In other words, while poverty and economic inequalities are important to migration, so are a receiving country's immigration policies, the political context of the sending country, and the social networks formed by migrants (Kritz and Zlotnik 1992: 3).

Just as neoclassical migration theory is founded on the presumption that the human person is a rational agent, migration systems theory is also founded on certain presumptions about the human person, namely that the person is indeed an rational, but also a relational agent. In this case, the anthropological presumptions of migration systems theory fit in quite well with some feminist critiques of the person as solely a rational agent. ${ }^{12}$ In particular, feminist ethicist Margaret Farley reconfigures autonomy from an impoverished account of autonomy as rational agency to a rich account of autonomy that insists that our decisions always occur in the context of our relations to one another, our communities and the past. Farley’s phrase "autonomy-in-relationality" captures how our autonomy is "a response to what we already are and to what has become possible for us in terms of where we are” (Farley 1993: 196). In other words, all expressions of autonomy take place within a context.

Farley's description of the human person can help describe what is going on in migration systems theory. Even though I have emphasized the macro-structures of migration in order to distinguish migration systems theory from neoclassical migration theory, it would be a mistake to view migrants as lacking agency, dragged around by historical forces and social networks. Migrants are indeed rational agents. They do make

\footnotetext{
${ }^{12}$ For a summary of feminist philosophical critiques of autonomy, see (Mackenzie and Stoljar 2000)
} 
decisions about maximizing outcomes for themselves and their families. Many first person accounts of migration describe how difficult it was for the migrant to leave the familiarity of home, but the push of need and the pull of a promise of a better life- often for their children or families-lured them away.

These decisions to migrate, however, are historically embedded. Farley writes that this embeddedness is part of relationality. "[Persons] are in biological, psychological, cultural history, and their history is in them like the rings of a tree,” (Farley 1993: 195). To be connected to other people is to be connected to communities that pre-exist individuals. Our connections to our families, cultures, religions, and nation-states place us in relation with those who have gone before us. Thus, the decision to migrate is historically conditioned, though not determined, by relationships between political communities.

Just as migrants are connected to their political communities and to the histories of the political communities of which they are a part, past and present, migrants are social beings who are connected to their families and informal communities. The desire and the need to reunite families drives migration. Migration is also driven by the need to provide for families who remain in the sending country by sending remittances and providing a kind of insurance against disaster (Massey et al. 2005: 21-26). Migrant networks are based on this relationality.

The communal self-determination of citizens is a kind of autonomy-in-relation. Farley writes that our actions belong to us, yet they are "not wholly our own,” (Farley 1993: 195). While theorists from Borjas to Walzer assume that the political community has the right and the ability to close its borders if it so chooses, migration systems theory 
shows how the autonomy of political communities is circumscribed to a certain extent by their former incarnations. Colonialism and post-war guest-worker programs were foreign policy decisions from decades ago, centuries, in some cases. The migration systems that these programs initiated, however, are still in place today.

In other cases, migration systems were initiated by foreign investment that never intended to bring migrants home along with profits. Saskia Sassen describes how foreign investment and manufacturing outsourcing can bring about the conditions for emigration by disrupting traditional work structures. When factories fire workers or close, the newly unemployed workers are far more likely to migrate, having already migrated once internally (Sassen 1988: 18). While neither economic policies of the host countries nor the actions of multi-national corporations were intended to initiate migration systems, political communities cannot erase the past. Regardless of the intentions of the political community, the migrant network, once in place, continues to bring new migrants. Though political communities are legally almost unconstrained in setting immigration policy, immigration policy cannot end migration systems at will.

Examining neoclassical and migration systems approach to undocumented migration illustrates the differences between these two theories. While neoclassical migration theory presumes that political communities can control undocumented migration by making the costs of migrating high enough, (Borjas 1999: 204) migration systems theorists present an alternate account of undocumented migration. Once a migration flow begins, migrant networks sustain the flows, which continue regardless of whether the state has authorized it or not. Often, when a state reduces or eliminates one category of entry (work visas), numbers of migrants will increase in another (undocumented 
migration) (Sassen 1996: 79). Undocumented migration is the result of the unintended consequences of not only of the state foreign and economic policies of the past, but also of the immigration policies of the present (Sassen 1996: Ch.3).

Focusing exclusively on the self-determination of citizens, as Carens, Walzer, and Miller all do, to exclude misses the moral and practical limits on self-determination. In other words, "our actions are not wholly our own;” (Farley 1993: 195) they are held and bound by the actions of our prior and present incarnations. Even Carens' argument for open borders neglects the relational dimension of migration, instead emphasizes an acontextual autonomy that treats all migrants alike. Walzer and Miller, in focusing on communal self-determination, miss the fact that the very ability to exclude is limited by the unintended consequences of past policies. ${ }^{13}$ The political community, just like the individual, does have a measure of self-determination, but such self-determination can only be deployed in real, historical contexts in which actions are constrained and often have unintended consequences for which the political community may be responsible.

\section{Migration Systems Ethics}

Farley challenges the model of person as autonomous rational agent by focusing on the person as a relational being. This shift from autonomy to autonomy-in-relation raises questions about the validity of migration ethics that explicitly or implicitly assume migration works as neoclassical migration theory describes. If migration systems theory

${ }^{13}$ Walzer does acknowledge that guestworker policies have had such unintended consequences, but the continued presence of guestworkers in the territory is presented as an exception to Walzer's strong account of self-determination and not as a typical example of how migration occurs. 
better reflects the autonomy-in-relationality of the human person, what would a migration ethics look like when rooted in migration systems theory? Although a full answer to this question is beyond the scope of this paper, I wish to suggest an initial answer in suggesting that an ethics rooted in migration systems theory would focus on justice-inrelation as the ethical norm.

As we have seen, the ethics of migration cannot focus exclusively on freedom and self-determination. Instead, migration systems theory describes migration as the result of the interaction of the choices of migrants and their relationships, both the relationships between citizens and would-be migrants and the relationships migrants have with one another.[Rajendra Forthcoming] These relationships enable the genesis and continuation of migration flows. As I described above, having such relationships necessarily follows from the fact that the human person is a relational being. However, relationships between people are not necessarily mutually beneficial; relationships between people can just as often be characterized by exploitation.

Exploitation in relationships between migrants and citizens takes at least two forms. First, migrants and citizens are in relationship with each other through the histories of colonialism and guest worker programs. Though many of these policies have ended, the relationship between contemporary citizens and those from former colonies continues through on-going migration. A second way that citizens are in relationship with migrants is that migrants provide low-cost labor to citizens. This labor connects migrants to citizens through relationships that provide benefits to citizens at the cost of the well-being of migrants. These two kinds of relationships often overlap in contemporary migration systems. For example, migrants from Mexico in the United States are a part of a 
migration system which has its roots in the complex relationship between the two countries, a relationship that includes organized labor recruitment. However, Mexican migrants are also exploited by immigration policies which leave immigrants unprotected in the labor market and keep the cost of migrant labor low.

Most accounts of distributive justice, which seeks to assign norms for the distribution of benefits and burdens in a society, are not sufficient to address the ethical issues raised by migration systems theory because such accounts rarely have a way to analyze the nature of the relationships that lead to migration systems. As an alternative to contemporary accounts of distributive justice, I propose a retrieval of justice as a relational concept.

In the thought of Thomas Aquinas, justice is the virtue that governs relationships between people (Aquinas, Summa Theologiae, II-II, Q. 58, A. 2). This perspective on justice is rooted in what contemporary moral theologians have retrieved as Thomas's relational anthropology; humans are constantly navigating relationships with one another, making justice one of the four cardinal virtues. Because neither Thomas and nor any of his contemporaries address the structural element of justice, Thomistic justice is insufficient by itself to address the human rights of migrants. ${ }^{14}$ Certainly the structures of labor recruitment in the West and abroad play a role in perpetuating the human rights abuses to which migrants are subjected, as does the willful ignorance of the citizens of Western democracies in relying on cheap labor. ${ }^{15}$ However, I wish to retrieve this Thomistic insight as a foundation of an ethics of migration: justice-in-relation, rather than the maximization of freedom, is the ideal for which we should strive.

\footnotetext{
14 Jean Porter points out this distinction between justice in the thought of Aquinas and justice in the thought of contemporary philosophers like John Rawls (Porter 2002: 277).

${ }^{15}$ For an extensive discussion of social sin and immigration, see (Heyer 2010).
} 
If the key ethical issue of contemporary migration is unjust relationships, then migration systems ethics requires determining what justice-in-relation looks like between migrants and citizens. I would suggest that this requires an evaluation of the relationships in question. Although every person, whether migrant or citizen, is endowed with rights by virtue of their humanity, every person cannot have the same claim on every other person. For example, common sense would tell us that what is owed to our children and parents is more than what we owe to a distant stranger. ${ }^{16}$ In this case, it is the nature of the relationship itself that demands special responsibilities that exceed what we would owe to a stranger.

In the case of distributive justice, many theorists would say that we have special responsibilities to fellow members of our societies. (Rawls 2001; Walzer 1983: 20, 40) However, if the nature of the relationship between migrants and citizens is not, in fact, a relationship between strangers, only governed by the principle of mutual aid, but a far closer relationship, then justice may require more than the principle of mutual aid. Thus determining what is owed to migrants requires reflections on the nature of such relationships and judgments about the obligations that emerge from these relationships.

As an example of this kind of reflection and judgment, I draw again on Michael Walzer, who makes a brief mention of a relationship that merits further examination. While his overall framework emphasizes the self-determination of the political community, he has a few notable exceptions in which he considers relationships between political communities. In his discussion of refugees and the claims of necessity, Walzer mentions that obligations to refugees are stronger than the principle of non-refoulement in

\footnotetext{
${ }^{16}$ Aquinas does consider the question of the love of the near and distant neighbor, but this is considered under questions about charity, not justice (Aquinas, Summa Theologiae, II-II, Q. 26). (See also Pope 1994: Ch. 2.)
} 
cases where a political community has had a role in turning people into refugees. He cites American involvement in Vietnam as an example, writing "The injury we have done them makes for an affinity between us; thus Vietnamese refugees had, in a moral sense, been effectively Americanized before they even reached our shores,” (Walzer 1983: 49). The obligation, in this case, is as strong as the obligation to fellow members; this obligation begins not with the self-determination of the political community, but in the relationship between Americans and the refugees, a relationship that began in a past injury.

Although this example is the exception to Walzer's strong stance on communal selfdetermination, migration systems theory suggests that such relationships between sending and receiving countries are more the rule than the exception. Following Walzer's own logic, the obligation to many migrants is much stronger than the principle of mutual aid because the economic and foreign policies of host countries have initiated migration flows that continue to this day. The relationship between citizens and potential migrants from former colonies is stronger than the relationship between citizens and potential migrants from countries with no historical connection; justice in those cases may require inclusion in the political community. ${ }^{17}$ Similarly, the relationship between citizens and potential migrants from countries where intervention has caused great harm, such as Walzer's example of the United States and Vietnam, creates a tie that requires more than the principle of mutual aid if justice is to govern such relationships.

Relationships between citizens and migrants need not be based on past harms in order to require inclusion in the norms of distributive justice. In many cases, the exploitative relationships begun in the past continue today through the structures of exploitative work,

${ }^{17}$ Elsewhere, I have addressed the responsibilities that such relationships generate (Rajendra Forthcoming) 
in which citizens and migrants are connected through the labor of migrant workers. Thus basic labor protections for workers and their families would be a minimum requirement of justice. Similarly, justice also demands that migrant workers are able to take advantage of the full scope of educational opportunities available to citizens. To exclude migrants and their children from educational opportunities would keep them in a permanent service class, maintaining unjust relationships.

The relational justice that I have described does not exclude considerations of the agency and freedom of both migrants and citizens. In fact, the concept of freedom is not out of place in discussions about the lengthy detentions and deportations of migrants. ${ }^{18}$ Such practices are problematic in part because they are unjust affronts to human freedom. In the case of immigrant detentions, it is reasonable to claim that no person should be subject to such a practice simply because it is such a dramatic affront to freedom, regardless of what the relationships between citizens and a particular group of migrants may be. However, when we approach questions of what must be done with detained migrants, questions about justice-in-relationships and the relationships between migrants and citizens are impossible to avoid.

Similarly, discussions about the communal self-determination of the political community in setting foreign, economic, and immigration policy is also sometimes appropriate, especially in contexts where this self-determination has been threatened through colonization, such as East Timor or Tibet. ${ }^{19}$ However, in such cases, such discussions about self-determination must be in the context of the relationships between migrants and citizens. Self-determination for East Timor or Tibet may necessitate

\footnotetext{
${ }^{18}$ For a historical account of deportation in the United States, see (Kanstroom 2007)

19 This point comes from a conversation with Daniel Kanstroom.
} 
limiting or preventing migration from Indonesia or China; such a conclusion is only available if we examine the nature of the relationships between the political communities.

\section{Conclusion.}

Just as ethicists would not exclusively use rational agent economic accounts in discussions of distributive justice, rational agent accounts of migration leave us with impoverished ethics of migration that overemphasize freedom and obscure the need for justice. The migration systems ethics that I have present here presumes an account of the person as a relational agent whose decisions take place in relational contexts. These relationships can often be exploitative, thus the central question of the ethics of migration is not about how to maximize the freedom of either citizens of migrants, but how to pursue justice in the relationships between migrants and citizens.

I have focused on the need for justice in migration systems, however, justice in relationships could also be used as a framework for evaluating migrant networks themselves. Some migrant networks are an expression of the sociality of migrants who come together to help each other; other migrant networks are based on relationships of exploitation of the vulnerabilities of migrants. Still other migrant networks are uncomfortable mixes of the two.

Viewing justice as a problem of relationships between people enables us to tackle one of the most difficult problems in the ethics of immigration: Who should be included in the political community, and thus the common good? Who should be included in our sphere of concern? The idea of justice-in-relationships can move us towards an answer to these questions. 


\section{Works Cited.}

Borjas, GJ (1990) Friends or strangers: the impact of immigrants on the U.S. economy. Basic Books, New York

Borjas, GJ (1999) Heaven's door: immigration policy and the American economy. Princeton University Press, Princeton, N.J.

Carens, JH (1987) Aliens and citizens: the case for open borders. The Review of Politics 49: $251-273$

Carens, JH (2000) Open borders and liberal limits: A response to Isbister. International migration review 34(2): 636-643

Carens, JH (1996) Realistic and idealistic approaches to the ethics of migration. International Migration Review 30: 156-170

Carens, JH (1997) The Philosopher and the Policy Maker: Two Perspective of the Ethics of Immigration with Special Attention to the Problem of Restricting Asylum. In: K Hailbronner, Martin, DA, and Motumora, H(eds.) Immigration Admissions: The Search for Workable Policies in Germany and the United States. Berghan Books, Providence, R.I., pp. 3-50

Carens, JH (2003) Who Should Get In?: The Ethics of Alien Admissions Ethics and International Affairs 17: 95-110

Carens, JH (2008) Live-in Domestics, Seasonal Workers, and Others Hard to Locate on the Map of Democracy Journal of Political Philosophy 16: 419-445

Carens, JH (2013) The Ethics of Immigration. Oxford University Press, New York Carrington, WJ (1999)

Castles, S, and MJ Miller (2009) The age of migration: international population movements in the modern world. Guilford Press, New York

Faist, T (2000) The volume and dynamics of international migration and transnational social spaces. Clarendon Press, Oxford

Farley, MA (1993) A Feminist Version of Respect for Persons Journal of Feminist Studies in Religion 9: 183-198 
Heyer, KE (2010) Social Sin and Immigration: Good Fences make Bad Neighbors Theological Studies 71: 410-436

Kanstroom, D (2007) Deportation nation : outsiders in American history. Harvard University Press, Cambridge, MA

Kritz, MM, and H Zlotnik (1992) Global Interactions: Migration Systems, Processes, and Policies. In: MM Kritz, Lim, LL, and Zlotnik, H(eds.) International migration systems : a global approach, Oxford University Press, Oxford, pp. 1-34

Lowenstein, Roger (2006) The Immigration Equation. New York Times

Mackenzie, Catriona, and Natalie Stoljar, eds. (2000) Relational autonomy : feminist perspectives on automony, agency, and the social self. Oxford University Press, New York

Massey, DS, J Arango, G Hugo, A Pellegrino, and JE Taylor (2005) Worlds in motion: understanding international migration at the end of the millennium. Oxford University Press, New York

Miller, D (2007) National responsibility and global justice. Oxford University Press, New York

Pope, SJ (1994) The evolution of altruism and the ordering of love. Georgetown University Press, Washington, D.C.

Porter, J (2002) The Virtue of Justice (IIa IIae, qq. 58-122). In: SJ Pope(ed.) The Ethics of Aquinas. Georgetown University Press, Washington, D.C., pp. 273-286

Portes, A (1997) Immigration theory for a new century: Some problems and opportunities. International Migration Review 31: 799-825

Portes, A, and J Böröcz (1989) Contemporary Immigration: Theoretical Perspectives on Its Determinants and Modes of Incorporation International Migration Review 23: 606630

Rajendra, TM (forthcoming) Justice, Not Benevolence: Catholic social thought, migration theory and the rights of migrants. Political Theology

Rawls, J (1999) The law of peoples. Harvard University Press, Cambridge, MA

Sassen, S (1988) The mobility of labor and capital : a study in international investment and labor flow. Cambridge University Press, Cambridge

Sassen, S (1996) Losing control?: sovereignty in an age of globalization. Columbia University Press, New York 
Sassen, S (1999) Guests and aliens. New Press, New York

Skeldon, R (1997) Migration and development: a global perspective. Addison-Wesley Longman Higher Education, London

Walzer, M (1983) Spheres of justice : a defense of pluralism and equality. Basic Books, New York 